\title{
Survey of facility and management characteristics of large, Upper Midwest dairy herds clustered by Dairy Herd Improvement records
}

\author{
R. L. Brotzman, D. Döpfer, M. R. Foy, J. P. Hess, K. V. Nordlund, T. B. Bennett, and N. B. Cook \\ School of Veterinary Medicine, University of Wisconsin, 2015 Linden Drive, Madison 53706
}

\begin{abstract}
A survey of management practices was conducted to investigate potential associations with groupings of herds formed by cluster analysis (CA) of Dairy Herd Improvement (DHI) data of 557 Upper Midwest herds of 200 cows or greater. Differences in herd management practices were identified between the groups, despite underlying similarities; for example, freestall housing and milking in a parlor. Group 6 comprised larger herds with a high proportion of primiparous cows and most frequently utilized practices promoting increased production [e.g., $84.4 \%$ used recombinant bovine somatotropin (rbST)], decreased lameness (e.g., 96.9\% used routine hoof trimming for cows), and improved efficiency in reproduction [e.g., 93.8\% synchronized the first breeding in cows (SYNCH)] and labor (e.g., mean $\pm \mathrm{SD}, 67 \pm 19$ cows per 50 -h per week full-time equivalent worker). Group 1 had the best mean DHI performances and followed most closely group 6 for the rate of adoption of intensive management practices while tending to outperform group 6 despite a generally smaller mean herd size (e.g., $42.3 \pm 3.6 \mathrm{~kg}$ vs. $39.9 \pm 3.6 \mathrm{~kg}$ of energy-corrected milk production; $608 \pm 352$ cows vs. $1,716 \pm 1,405$ cows). Group 2 were smaller herds with relatively high levels of performance that used less intensive management (e.g., 100\% milked twice daily) and less technology (33.3 vs. $73.0 \%$ of group 1 used rbST). Group 4 were smaller but poorer-performing herds with low turnover and least frequently used intensive management practices (e.g., 39.1\% SYNCH; 30.4\% allowed mature, high-producing cows access to pasture). Group 5 used modern technologies and practices associated with improved production, yet had the least desirable mean DHI performance of all 6 groups. This group had the lowest proportion of deep loose-bedded stalls (only $52.2 \%$ used sand bedding) and the highest proportion $(34.8 \%)$ of herds not using routine hoof trimming. The survey of group 3 herds did not reveal strong trends in
\end{abstract}

Received December 19, 2014.

Accepted June 13, 2015.

${ }^{1}$ Corresponding author: nbcook@wisc.edu management. The differences identified between herd groupings confirm significant variation in management practices linked to variation in overall herd performance measured by DHI variables. This approach provides an opportunity for consultants and outreach educators to better tailor efforts toward a certain type of dairy management philosophy, rather than taking a blanket approach to applying recommendations to farms simply because of their larger herd size.

Key words: cluster analysis, Dairy Herd Improvement data, management, housing

\section{INTRODUCTION}

Dairy farmers are continually striving to improve their profitability through increased production efficiency, achieved through the use of specific technologies and management practices they believe will enhance their bottom line. Measuring production performance after the adoption of such technologies or practices is essential to monitoring efficiency. This can theoretically be accomplished by different metrics of milk production, reproductive efficiency, cow health, and longevity, typically using a vast number of routinely collected DHI test-day variables. However, management decisions may affect more than one area of performance, and no single DHI variable entirely encompasses the overall performance of a herd. As previously discussed, many DHI variables are also strongly correlated with herd size and milk production and not necessarily associated with preferred outcomes of all production variables (Brotzman et al., 2015).

Because the processes and outcomes of milk production, reproduction, health, herd size, and management strategies are interconnected, the need to optimize each area simultaneously for the most efficient use of limited resources on farms for maximum profit adds a level of complexity (Enevoldsen et al., 1995; Galligan, 1999, 2006). To further complicate these decisions, there exists an ever-increasing concern among both consumers and those involved in dairy production over the social responsibilities of dairy farms that are growing in size and using more intensive management practices, including issues of animal well-being, food safety, and 
environmental impact resulting from the push to produce more milk more efficiently (von Keyserlingk et al., 2013). Indeed, $75.6 \%$ of milk produced in the United States in 2012 was produced on dairy farms of 200 or more cows (USDA-NASS, 2012) and in Wisconsin, herds of 200 or more cows are most likely to be managed in an intensive manner with freestall barns and use of a milking parlor (USDA-NASS, 2010).

Brotzman et al. (2015) further described the need to define a method for classifying herds' overall performance that is not biased toward the largest herds, the highest milk yield, or the best performance in any single variable. The approach proposed used cluster analysis (CA) as a potential solution, involving the recognition of patterns of DHI variables that best describe overall performance of a group of herds. Cluster analysis offers a method of dividing entities into groups based upon similarity in multiple characteristics simultaneously (Borcard, 2011). Groupings of dairy herds with similar performance characteristics were developed to categorize herds on multiple variables simultaneously, without preconceived ideas regarding the relationships among the selected variables and their association with management practices. Principal component analysis (PCA) was applied to mean year 2011 DHI data for 557 Upper Midwest dairy herds of $\geq 200$ cows on test to determine the most meaningful subset of variables to describe the herds, followed by CA to categorize the herds into groups in an outcome-independent way (Brotzman et al., 2015).

The aim of this project was to subject herds in each cluster group to a survey questionnaire to gain knowledge of herd management and facility characteristics that may have influenced the CA grouping. Our hypothesis was that different management choices were associated with the grouping structure created by CA using DHI parameters, thereby identifying performance and management patterns on dairies that would be receptive to different outreach efforts. These efforts could then be targeted at specific areas in different groups with the ultimate goal of increasing overall uptake and effectiveness of management best practices, facility design, and technology use.

\section{MATERIALS AND METHODS}

Methods for PCA and CA of DHI data for year 2011 for 557 Upper Midwest herds of $\geq 200$ cows were previously described (Brotzman et al., 2015). Data were made available from AgSource Cooperative Services (Verona, WI) and included dairies located primarily in Wisconsin but also in Minnesota, Iowa, Illinois, and Michigan. Farms were divided into 6 groups by CA using the 16 PCA-selected DHI variables (Table 1). Ran- domly selected herds from each group were contacted by telephone to complete a survey of management and housing practices until approximately one-third of each group had been surveyed or time and attempts to contact producers had been exhausted during the period of June through August 2012. The survey was designed to be completed by a manager, owner, or other individual who had a good working knowledge of the dairy. Goal time to complete the survey was 10 to $15 \mathrm{~min}$, with the aim of improving the response rate while gathering basic information about the management of each farm, indicators of the adoption of modern technologies, housing and management practices, and the amount of labor committed to the management, care, and milking of the herd. Three individuals called producers and collected survey information from June through August 2012, each following a written script as they introduced the study and asked questions to ensure consistency. Respondents were assured that answers would be kept confidential. Information provided would not be publicly published in any way that would associate their replies or DHI data with their farm.

The survey tool sought general information about the herd, its management, and the adoption of technologies, including the predominant breed or crossbreed, whether conventional or organic management practices were primarily used, how often per lactation cows were routinely hoof trimmed, and if heifers were routinely hoof trimmed before calving. The number of ration groups for the dry period was collected, as well as information on where cows calve (individual or group pen) and how long they stay in the pen in which they calve. Regarding specific technology adoption, the survey asked which, if any, reproductive synchronization program was used routinely for the first breeding in cows (SYNCH), as well as the use of monensin and the proportion of cows treated with recombinant bST $(\operatorname{rbST})$.

In regards to milk quality and harvesting, information was gathered on which types of products if any were used in the udder at dry off (i.e., antibiotic or an internal teat sealant) and what proportion of cows were treated with intramammary antibiotic at dry off. Producers were asked to answer questions on how milk was harvested on the dairy, including parlor design and size, the number of cows in the largest milking group, number of parlor turns required to milk the largest group of cows, number of times per day the high group of mature cows (around 100 DIM) was milked, frequency of milking the early-lactation cows (around 5 DIM, not including colostrum or treated cows), and whether or not treated cows were individually tested on-farm for drug residues before adding their milk into the saleable milk tank. 
Facility design and management questions were asked in regards to where the highest-producing, second- and greater-lactation cows were housed. These questions sought answers regarding type of housing (e.g., freestall barn, bedded pack), the use of headlocks at the feedbunk, number of fresh feed deliveries per day, ventilation system, alley floor construction and how they are cleaned, whether first-lactation cows were grouped together or separately from mature cows, stall surface (e.g., deep bedding vs. man-made rubber surface), type of bedding, method of sand recycling or generating manure solids (where applicable), number of rows of stalls in the freestall pen and type of stall layout (where applicable), and whether or not the high-producing, mature cows had access to a pasture or dirt lot.

Finally, estimations of labor involved with the dairy operation were made. To estimate the number of 50-h per week full-time equivalent (FTE) workers involved with each dairy, producers were asked questions to determine the number of people and hours per day they were involved in the care of each aspect of the farm that directly involved the herd (e.g., calf care, milking, mixing and delivering feed, cleaning, management, manure hauling), not including feed production. To further characterize the use of labor on the dairy, herds were asked if calves or heifers were sent to a custom raiser at any point during their rearing (CUST).

Descriptive statistics for the PCA-selected DHI variables and survey questions were computed per cluster group. Normality of distribution of the continuous variables from both the survey and year 2011 DHI data of surveyed herds was assessed. The natural log was applied to several variables to improve normality, including time spent in the calving pen, number of parlor units, number of cows in the largest milking group, number of parlor turns required to milk the largest group, total FTE, cows per FTE worker (cows/ FTE), mean herd size on test, mean proportion of the herd with a new IMI (defined as having a previous testday SCC $<200,000$ cells $/ \mathrm{mL}$ and current test-day SCC $>200,000$ cells $/ \mathrm{mL}$ ), mean proportion of the herd with an IMI at the first test of lactation (defined as having an SCC $<200,000$ cells $/ \mathrm{mL}$ at the last test before dry off and first test day of the following lactation an SCC $>200,000$ cells $/ \mathrm{mL}$ ), mean proportion of the herd that died (DIED), and mean proportion of the herd that died by 60 DIM (DIED60). Continuous variables were examined for strong correlations $(|\mathrm{r}|>0.9)$. Log of herd size and $\log$ of total FTE were strongly correlated $(\mathrm{r}=$ $0.902)$, as were the log of new IMI rate with the mean linear SCS $(r=0.908)$.

To prepare the data for assessing the association of survey answers with cluster groups, categorical answers for questions that had low frequencies $($ count $<5)$ in more than $20 \%$ of the answer categories were combined when possible into logical categories, including primary breed in the herd (Holstein or other), number of routinely scheduled hoof trimmings per lactation $(0$, 1 or $\geq 2$ trims per lactation), presence of headlocks at the feed bunk fence (none vs. some or all headlocks), number of times per day fresh feed is delivered to the high-producing mature cows ( 1 or $\geq 2$ deliveries per day), method of cleaning floors in the high-producing mature cow pen(s) (automatic/flush/slatted floor vs. skid loader/tractor/vacuum truck), and bedding type (sand or other). If no meaningful categories of answers could be made (e.g., too many groups had no or too few herds answering in each of the categories), the variable was removed from the analysis, which included pasture access for the highest-producing mature cows, utilization of organic management practices, synchronization program type, use of rubber flooring in the pen, use of rubber flooring in the transfer lane from the barn to the parlor, parlor design, milking frequency of the highproducing mature cows around 100 DIM and of fresh cows around 5 DIM, use of dry-cow antibiotic therapy, use of an internal teat sealant at dry off, housing facility type (all herds except one had freestall barns), construction type of the alley floor for the high-producing mature cow group(s), sand recycling and method, and manure solids generation method.

A multivariate ANOVA (MANOVA) between groups was performed on the DHI and survey continuous numerical variables using PROC GLM in SAS (SAS Institute, 2008) with a Bonferroni correction for multiple comparisons of least squares means (LSM) at error level $\alpha<0.05$. A multinomial logistic regression with cluster group as the outcome variable was attempted using PROC GLIMMIX in SAS; however, the resulting model had a poor fit with unrealistic odds ratio results and is not reported.

\section{RESULTS AND DISCUSSION}

Descriptive statistics of the 16 PCA-selected, year 2011 mean test-day DHI variables for the 201 surveyed herds are summarized in Table 1 overall and by CA group. The MANOVA (Table 2) demonstrated a significant effect of each PCA-selected variable on group categorization $(P<0.05)$. Least squares means and significant differences $(P<0.05)$ between groups in each DHI variable are shown in Table 3 . The MANOVA results supported the use of CA in categorizing herds and indicated that surveyed herds were representative of the entire population of 557 dairy herds initially submitted to CA.

The survey revealed trends in herd management consistent with DHI performance of each cluster group. Re- 


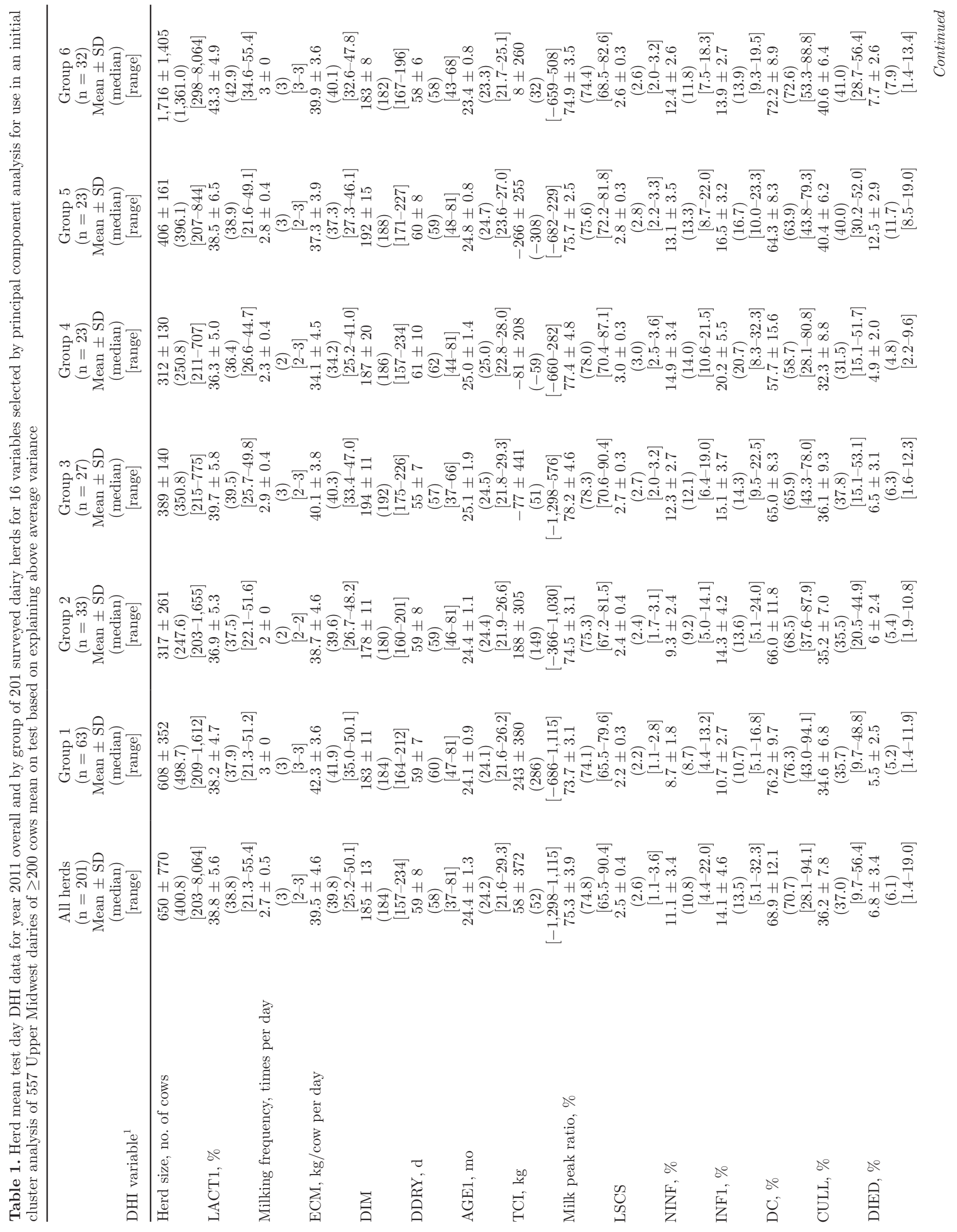


sults should be interpreted in light of 2 limiting factors. First, DHI is a voluntary program and herds included in this survey likely either have a greater awareness of the importance of monitoring these variables than herds not enrolled in DHI, or do not self-test using commercially available equipment and computer programs. Second, the study was limited to herds located in the Upper Midwest, resulting in potential regional bias in both DHI performance and management practices (Oleggini et al., 2001; Smith et al., 2000, 2002).

Table 4 summarizes the frequency of categorical survey questions, overall and by group. Descriptive statistics for continuous variable survey responses are summarized in Table 5, overall and by group. Relative rank of cluster groups by highest rate of adoption of technology, management, and housing practices that promote improved production, animal well-being, and labor efficiency are shown in Figure 1. Overall, 36.1\% of the 557 eligible herds completed the survey. Group 6 had the highest rate of respondents (43.2\%) and group 3 had the lowest rate of respondents (27.8\%). Ranges in each continuous survey variable overlapped between groups. The MANOVA demonstrated a significant effect of each continuous survey response variables between groups $(P<0.05$; Table 2$)$ except for the proportion of cows treated with an intramammary antibiotic at dry off $(P=0.08)$. Least squares means and significant differences at an error level of $\alpha<0.05$ between groups in each continuous survey response variable are shown in Table 3. Surveyed herds overwhelmingly consisted of primarily Holstein cattle, with the other breeds represented throughout the 6 cluster groups. Organic management practices were limited to one dairy in group 4. The highest-producing, mature cows on all but one farm surveyed were housed in freestall barns.

\section{Group 6}

Group 6 was most notably separated from the other cluster groups, as it was most often found at the extreme end of survey response frequencies and means. In Brotzman et al. (2015), group 6 DHI measures characterized the group as larger herds with a high proportion of primiparous cows, most aggressive reproductive parameter performances and high production, but lagging in transition cow health indicators and having increased death rates. This survey revealed that group 6 herds were generally the largest and youngest herds, with a mean of $1,716 \pm 1405$ (mean \pm SD) cows and 43.3 $\pm 4.9 \%$ first-lactation cows (LACT1). These farms most frequently utilized intensive practices promoting increased milk production (e.g., 96.9\% milked 3 times daily, $84.4 \%$ of herds used rbST on a mean $74 \pm 37 \%$ of cows in the herd), increased attention to hoof care 
Table 2. Overall results of multivariate ANOVA of continuous survey variables and DHI data for 6 groups of 201 surveyed Upper Midwest dairy herds of year 2011 annual mean $\geq 200$ cows on test, from an initial 557 herds clustered by the 16 principal component analysis-selected DHI variables

\begin{tabular}{|c|c|c|c|c|}
\hline Variable $^{1}$ & df & $\begin{array}{l}\text { Type III sum } \\
\text { of squares }\end{array}$ & $\begin{array}{l}\text { Mean square } \\
\text { error }\end{array}$ & $P$-value \\
\hline \multicolumn{5}{|l|}{ DHI variables } \\
\hline Log herd size, no. cows & 5 & 54.1 & 10.8 & $<0.0001$ \\
\hline Milking frequency, times per day & 5 & 29.9 & 6.0 & $<0.0001$ \\
\hline $\mathrm{ECM}, \mathrm{kg} / \mathrm{cow}$ per day & 5 & $1,298.7$ & 259.7 & $<0.0001$ \\
\hline DIM per day & 5 & $4,986.4$ & 997.3 & $<0.0001$ \\
\hline TCI, kg & 5 & $6,141,488.8$ & $1,228,297.8$ & $<0.0001$ \\
\hline Milk peak ratio, $\%$ & 5 & 516.2 & 103.2 & $<0.0001$ \\
\hline LSCS & 5 & 13.6 & 2.7 & $<0.0001$ \\
\hline Log NINF, \% & 5 & 7.8 & 1.6 & $<0.0001$ \\
\hline INF1, \% & 5 & 8.5 & 1.7 & $<0.0001$ \\
\hline $\mathrm{DC}, \%$ & 5 & $7,781.0$ & $1,556.2$ & $<0.0001$ \\
\hline CULL, \% & 5 & $1,574.4$ & 314.9 & $<0.0001$ \\
\hline Log largest milking group size (no. of cows) & 5 & 6.1 & 1.2 & $<0.0001$ \\
\hline Log parlor turns required for the largest milking group (no. of cows) & 5 & 4.2 & 0.8 & $<0.0001$ \\
\hline Dry cows treated with intramammary antibiotic $(\%)$ & 5 & $3,613.2$ & 722.6 & 0.082 \\
\hline Cows treated with recombinant bST $(\%)$ & 5 & $75,664.6$ & $15,132.9$ & $<0.0001$ \\
\hline Log total FTE herd workers at $50 \mathrm{~h} / \mathrm{wk}$ (no.) & 5 & 47.1 & 9.4 & $<0.0001$ \\
\hline Log cows per FTE herd worker (cows/FTE) & 5 & 1.8 & 0.4 & 0.0013 \\
\hline
\end{tabular}

${ }^{1} \mathrm{LACT} 1=$ proportion of the herd as primiparous cows; $\mathrm{ECM}=3.5 \%$ energy-corrected milk, $\mathrm{kg} ;$ DDRY = days dry; AGE1 = age at first calving, mo; TCI $=$ Transition Cow Index, $\mathrm{kg}$; Milk peak ratio $=$ ratio of peak test-day milk production of primiparous to multiparous cows; LSCS $=$ linear somatic cell score $(\log$ SCC); NINF $=$ proportion of herd with a new IMI (previous test-day SCC $<200,000$ cells $/ \mathrm{mL}$ and current test-day SCC $>200,000$ cells $/ \mathrm{mL}$ ); INF1 = proportion of herd with a new IMI at first test (SCC at last test of previous lactation $<200,000$ cells $/ \mathrm{mL}$ and SCC at first test of current lactation $>200,000$ cells $/ \mathrm{mL}$ ); DC $=$ proportion of dry period IMI cured (SCC at last test of previous lactation $>200,000$ cells $/ \mathrm{mL}$ and SCC at first test of current lactation $<200,000$ cells $/ \mathrm{mL}$ ); CULL = proportion of herd culled; DIED $=$ proportion of herd died; DIED60 = proportion of herd died by 60 DIM; FTE $=50$-h per week full-time equivalent worker.

[e.g., scheduled hoof trimming for adult cows $(96.9 \%$ of herds) and prefresh heifers (53.1\%), and deep bedding (78.1\%)], improved efficiency in reproduction [e.g., $93.8 \%$ of herds use SYNCH, lowest age at first calving (AGE1) $23.4 \pm 0.8 \mathrm{mo}$, efficient milk harvesting (e.g., one of the lowest parlor turns to milk the largest group of cows on the dairy at $4.6 \pm 1.3$ turns per hour), and use of labor (e.g., $67 \pm 19$ cows per FTE and $78.1 \%$ of herds used CUST). The survey results from group 6 herds confirmed that farms that adopt one technology are more likely to adopt other technologies, and that this is particularly true of larger farms as surveyed throughout the United States (Khanal et al., 2010).

However, despite embracing production-enhancing strategies, ECM yield in group 6 tended to be lower than that in group 1, perhaps due to the greater proportion of primiparous cows or poorer early lactation performance. Although group 6 had the highest proportion of SYNCH herds, as a group they tended to be out-performed by group 2 , which achieved a numerically lower DIM $(178 \pm 11$ vs. $183 \pm 8$ d) with many fewer herds utilizing SYNCH (60.6\% vs. 93.7\%).
Group 6 herds generally utilized practices that should improve transition cow performance [e.g., separate ration groups for far-off and pre-fresh dry cows $(78.1 \%$ of herds), short duration of stay in a calving pen ( 0.76 $\pm 1.96 \mathrm{~d}$ ) and separate pens for multiparous and primiparous cows (96.9\%); Cook and Nordlund, 2004], yet as a group these herds did not exhibit any higher than industry-average Transition Cow Index (TCI; 8 $\pm 260 \mathrm{~kg}$ ) and had the highest rates of turnover [mean cull rate (CULL) $40.6 \pm 6.4 \%$; DIED $7.7 \pm 2.6 \%$; and DIED60 $2.8 \pm 1 \%$. The TCI is a measure of fresh cow performance patented by the Wisconsin Alumni Research Foundation and is available through AgSource Cooperative Services (Verona, WI); it represents the difference between predicted and actual first test 305-d milk.

Group 6 herds most efficiently used their labor forces on a cows/FTE basis. Although cows/FTE was statistically similar to that in group 2 and group 4 herds, group 6 herds numerically kept more cows per FTE, were larger, and performed differently with many similar DHI results to group 2 and many differences to 
Table 3. Least squares means and results of multivariate ANOVA by group of surveyed continuous variables and 16 principal component analysis-selected DHI variables for 201 Upper Midwest dairies of year 2011 mean $\geq 200$ cows on test categorized into 6 groups using cluster analysis of an initial 557 herds

\begin{tabular}{|c|c|c|c|c|c|c|}
\hline Variable $^{1}$ & $\begin{array}{c}\text { Group } 1 \\
(\mathrm{n}=171)\end{array}$ & $\begin{array}{l}\text { Group } 2 \\
(\mathrm{n}=86)\end{array}$ & $\begin{array}{l}\text { Group 3 } \\
(\mathrm{n}=97)\end{array}$ & $\begin{array}{l}\text { Group } 4 \\
(\mathrm{n}=67)\end{array}$ & $\begin{array}{l}\text { Group } 5 \\
(\mathrm{n}=62)\end{array}$ & $\begin{array}{l}\text { Group } 6 \\
(\mathrm{n}=74)\end{array}$ \\
\hline \multicolumn{7}{|l|}{ DHI variables } \\
\hline Log herd size, no. cows & $6.3^{\mathrm{b}}$ & $5.6^{\mathrm{c}}$ & $5.9^{\mathrm{bc}}$ & $5.7^{\mathrm{c}}$ & $5.9^{\mathrm{bc}}$ & $7.2^{\mathrm{a}}$ \\
\hline Milking frequency, times per day & $3.0^{\mathrm{a}}$ & $2.0^{\mathrm{d}}$ & $2.9^{\mathrm{ab}}$ & $2.3^{\mathrm{c}}$ & $2.8^{\mathrm{b}}$ & $3.0^{\mathrm{a}}$ \\
\hline $\mathrm{ECM}, \mathrm{kg} / \mathrm{cow}$ per day & $42.3^{\mathrm{a}}$ & $38.7^{\mathrm{b}}$ & $40.1^{\mathrm{ab}}$ & $34.1^{\mathrm{c}}$ & $37.3^{\mathrm{b}}$ & $39.9^{\mathrm{ab}}$ \\
\hline DIM per day & $183.3^{\mathrm{bc}}$ & $178.4^{\mathrm{c}}$ & $193.7^{\mathrm{a}}$ & $186.6^{\mathrm{abc}}$ & $191.9^{\mathrm{ab}}$ & $182.9^{\mathrm{bc}}$ \\
\hline TCI, $\mathrm{kg}$ & $242.7^{\mathrm{a}}$ & $188.4^{\mathrm{a}}$ & $-77.3^{\mathrm{bc}}$ & $-81.4^{\mathrm{bc}}$ & $-265.8^{\mathrm{c}}$ & $8.0^{\mathrm{ab}}$ \\
\hline Milk peak ratio, $\%$ & $73.7^{\mathrm{c}}$ & $74.5^{\mathrm{c}}$ & $78.2^{\mathrm{a}}$ & $77.4^{\mathrm{ab}}$ & $75.7^{\mathrm{abc}}$ & $74.9^{\mathrm{bc}}$ \\
\hline LSCS & $2.2^{\mathrm{c}}$ & $2.4^{\mathrm{c}}$ & $2.7^{\mathrm{b}}$ & $3.0^{\mathrm{a}}$ & $2.8^{\mathrm{b}}$ & $2.6^{\mathrm{b}}$ \\
\hline Log NINF, \% & $2.1^{\mathrm{c}}$ & $2.2^{\mathrm{c}}$ & $2.5^{\mathrm{b}}$ & $2.7^{\mathrm{a}}$ & $2.5^{\mathrm{ab}}$ & $2.5^{\mathrm{b}}$ \\
\hline Log INF1, \% & $2.3^{\mathrm{c}}$ & $2.6^{\mathrm{b}}$ & $2.7^{\mathrm{b}}$ & $3.0^{\mathrm{a}}$ & $2.8^{\mathrm{ab}}$ & $2.6^{\mathrm{b}}$ \\
\hline DC, $\%$ & $76.2^{\mathrm{a}}$ & $66.0^{\mathrm{b}}$ & $65.0^{\mathrm{bc}}$ & $57.7^{\mathrm{c}}$ & $64.3^{\mathrm{bc}}$ & $72.2^{\mathrm{ab}}$ \\
\hline CULL, \% & $34.6^{\mathrm{b}}$ & $35.2^{\mathrm{ab}}$ & $36.1^{\mathrm{ab}}$ & $32.3^{\mathrm{b}}$ & $40.4^{\mathrm{a}}$ & $40.6^{\mathrm{a}}$ \\
\hline Log largest milking group size, no. of cows & $4.7^{\mathrm{b}}$ & $4.8^{\mathrm{b}}$ & $4.7^{\mathrm{b}}$ & $4.7^{\mathrm{b}}$ & $4.6^{\mathrm{b}}$ & $5.2^{\mathrm{a}}$ \\
\hline $\begin{array}{l}\text { Log parlor turns required for the largest milking group, } \\
\text { no. of cows }\end{array}$ & $1.7^{\mathrm{ab}}$ & $2.0^{\mathrm{a}}$ & $1.7^{\mathrm{ab}}$ & $1.9^{\mathrm{ab}}$ & $1.7^{\mathrm{ac}}$ & $1.5^{\mathrm{c}}$ \\
\hline Dry cows treated with intramammary antibiotic, $\%$ & 98.6 & 100.0 & 90.2 & 87.4 & 95.6 & 96.8 \\
\hline Cows treated with recombinant bST, \% & $57.2^{\mathrm{a}}$ & $22.8^{\mathrm{b}}$ & $63.6^{\mathrm{a}}$ & $17.2^{\mathrm{b}}$ & $46.9^{\mathrm{ab}}$ & $73.7^{\mathrm{a}}$ \\
\hline Log total FTE herd workers at $50 \mathrm{~h} / \mathrm{wk}$, no. & $2.4^{\mathrm{b}}$ & $1.6^{\mathrm{e}}$ & $2.0^{\mathrm{cd}}$ & $1.6^{\text {de }}$ & $2.0^{\mathrm{bc}}$ & $3.1^{\mathrm{a}}$ \\
\hline Log cows per FTE herd worker, cows/FTE & $3.9^{\mathrm{b}}$ & $4.1^{\mathrm{ab}}$ & $3.9^{\mathrm{b}}$ & $4.0^{\mathrm{ab}}$ & $3.9^{\mathrm{b}}$ & $4.2^{\mathrm{a}}$ \\
\hline
\end{tabular}

${ }^{\mathrm{a} e} \mathrm{e}$ Least squares means within a row with different superscripts differ $(P<0.05)$.

${ }^{1} \mathrm{LACT} 1=$ proportion of the herd as primiparous cows; $\mathrm{ECM}=3.5 \%$ energy-corrected milk, $\mathrm{kg} ;$ DDRY = days dry; AGE1 = age at first calving, mo; TCI = Transition Cow Index, kg; Milk peak ratio = ratio of peak test-day milk production of primiparous to multiparous cows; LSCS = linear somatic cell score (log SCC); NINF = proportion of herd with a new IMI (previous test-day SCC $<200,000$ cells/mL and current test-day SCC $>200,000$ cells $/ \mathrm{mL}$ ); INF1 = proportion of herd with a new IMI at first test (SCC at last test of previous lactation $<200,000$ cells $/ \mathrm{mL}$ and SCC at first test of current lactation $>200,000$ cells $/ \mathrm{mL}$ ); DC $=$ proportion of dry period IMI cured (SCC at last test of previous lactation $>200,000$ cells $/ \mathrm{mL}$ and SCC at first test of current lactation $<200,000$ cells $/ \mathrm{mL}$ ); CULL = proportion of herd culled; DIED $=$ proportion of herd died; DIED60 = proportion of herd died by 60 DIM; FTE $=50$-h per week full-time equivalent worker.

group 4. Sampling from large US dairies with a mean herd size of 731 cows, Schefers et al. (2010) reported an average of $70 \pm 30.2$ cows/FTE, which is particularly similar to group 6 , but did not indicate a separation of labor dedicated to the dairy herd from labor involved in crop production, whereas the current survey asked specific questions to obtain accurate hourly work performed directly with the herd. Certainly, larger dairies will require more workers to care for the herd, yet larger dairies have the opportunity to implement strategies that increase the number of cows per worker compared with smaller herds. Also, with increased herd size, the decisions and work of the dairy farm owner have changed from directly managing cattle to managing labor, and finding and managing labor has been cited as a major challenge to expanding dairies in Wisconsin (Bewley et al., 2001b) and large dairies located throughout the United States (Caraviello et al., 2006). Although $96 \%$ of producers reported the most important personal benefit of modernization was perceived to be reducing labor per cow (Mayer and Kammel, 2008), results from the current survey indicate a potential for diminishing effectiveness of labor as efficiency increases on a per cow basis. Additional investigation is needed to determine if and what level of labor efficiency on dairy farms results in best overall herd performance.

\section{Group 1}

Group 1 herds most closely followed group 6 in these trends, while at times exceeding the adoption of some practices and having improved DHI performance. Group 1 herds exhibited the best mean udder health DHI variables, and also more frequently employed practices promoting prevention and cure of mastitis [e.g., use of an internal teat sealant (92.1\%) and an intramammary antibiotic at dry-off (100\%)], resulting in one of the lowest linear SCS (LSCS; $2.2 \pm 0.3$ ), risk of new IMI (NINF; SCC at previous test $<200,000$ cells/ $\mathrm{mL}$ and SCC at current test $>200,000$ cells/mL; $8.7 \pm$ 


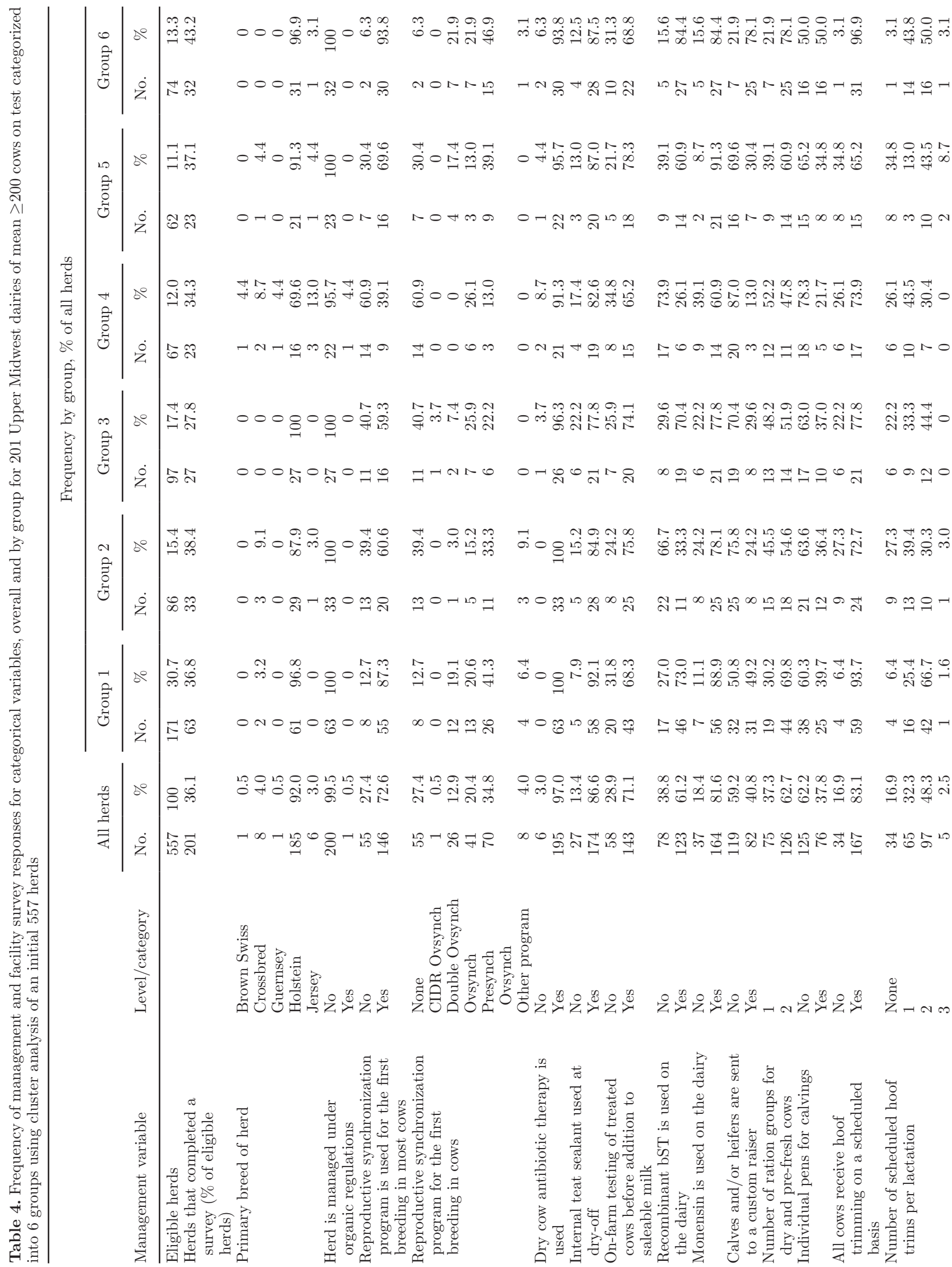




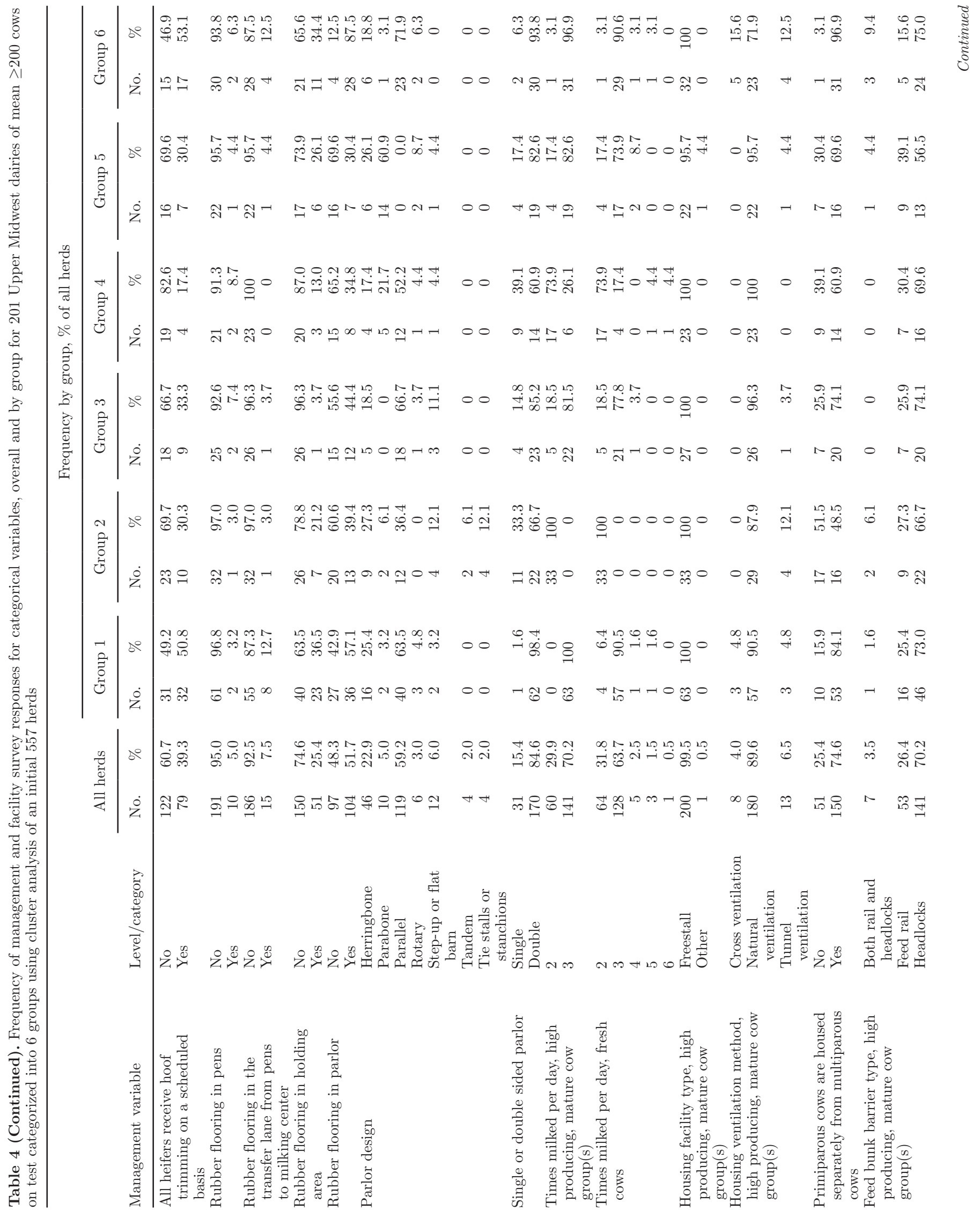




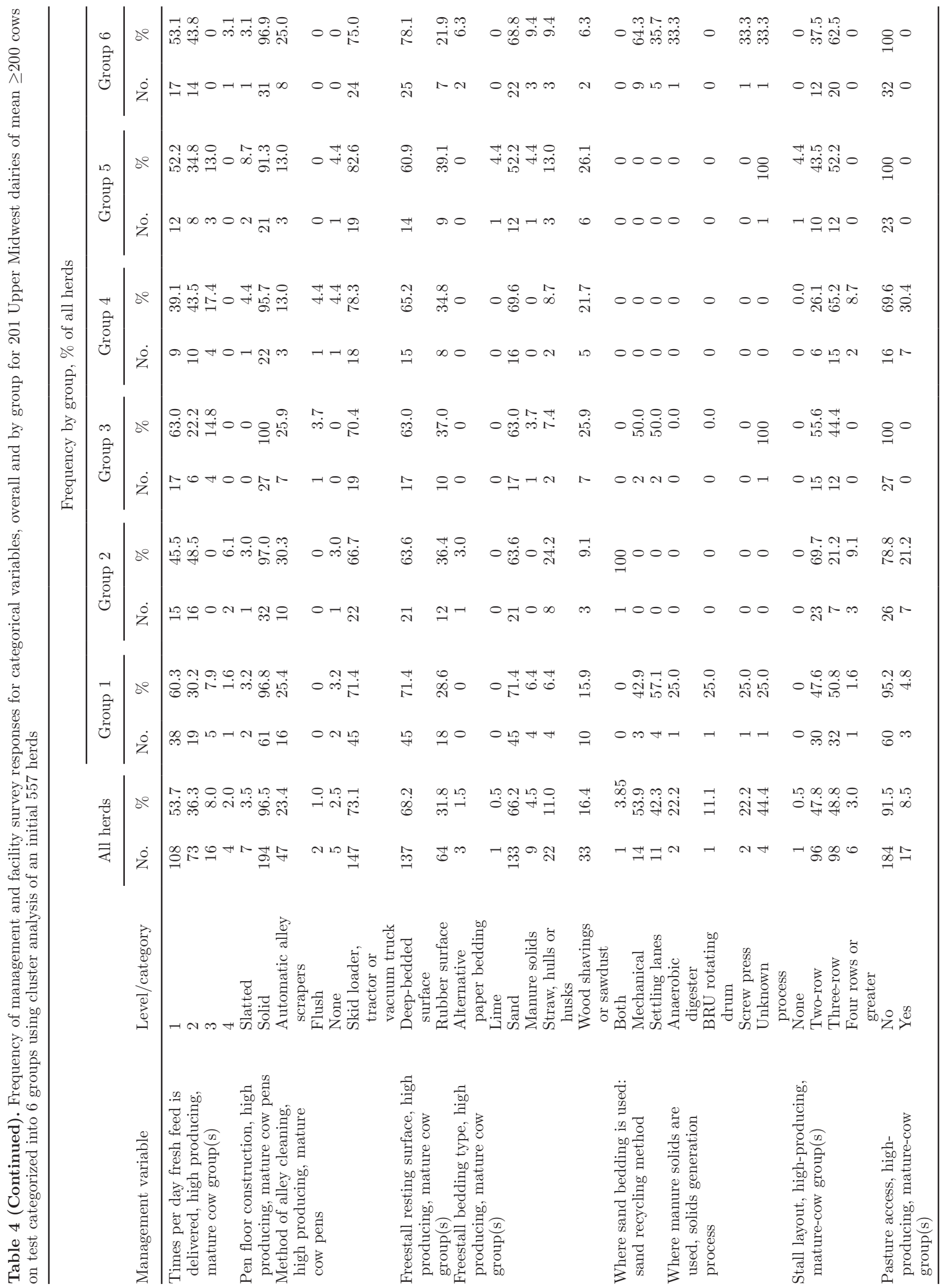


$1.8 \%$ ), and risk of new IMI at first test (INF1; SCC at last test of previous lactation $<200,000$ cells $/ \mathrm{mL}$ and SCC at first test of current lactation $>200,000$ cells/ $\mathrm{mL} ; 10.7 \pm 2.7 \%)$ as well as highest risk of dry period IMI cure (DC; SCC at last test of previous lactation $>200,000$ cells $/ \mathrm{mL}$ and SCC at first test of current lactation $<200,000$ cells $/ \mathrm{mL} ; 76.2 \pm 9.7 \%$ ). Similar to group 6, a high proportion of group 1 herds utilized SYNCH (87.3\%), which may explain the similarly low mean DIM for group 1 (183 \pm 11 d). Group 1 exceeded all other groups in the adoption of hoof care practices, having the highest proportion of herds trimming twice or more per lactation at $68.3 \%$ and use of sand bedding $(71.4 \%)$.

Although group 1 herds tended to out-produce group 6 herds in ECM $(42.3 \pm 3.6 \mathrm{~kg}$ vs. $39.9 \pm 3.6 \mathrm{~kg})$, they did so with fewer herds using rBST $(73.0 \%$ vs. $84.4 \%)$ on a smaller proportion of cows in each herd treated ( 57 $\pm 43 \%$ vs. $74 \pm 37 \%)$. Transition Cow Index tended to be highest among group 1 herds $(243 \pm 380 \mathrm{~kg})$, and this group frequently managed dry cows with 2 ration groups (69.8\% of herds). In contrast to group 6 , group 1 herds more frequently used group calving pens $(60.3 \%)$ and kept cows in these pens for longer periods $(6 \pm 9.35 \mathrm{~d})$, perhaps a result of the more frequent use of stable social grouping of prefresh cows, which has previously been associated with improved transition cow performance (Nordlund, 2011). Group 1 also had one of the lowest CULL rates among the 6 groups (36.2 $\pm 7.8 \%)$ and mean proportion of the herd that died $(5.5 \pm 2.5 \%)$.

The labor force of group 1 herds was much smaller than group $6(11.6 \pm 11.8$ FTE vs. $26.7 \pm 20.2 \mathrm{FTE}$, respectively), with each worker responsible for proportionately fewer cows $(56 \pm 18$ cows/FTE in group 1 vs. $67 \pm 19$ cows/FTE in group 6), and therefore increasing worker time available per cow, perhaps contributing to better overall herd performance. For example, group 1 herds had significantly lower CULL (LSM $34.6 \%$ vs. $40.6 \%, P<0.05$ ) and DIED (LSM $1.6 \%$ vs. $2.0 \%, P$ $<0.05$ ), a finding similar to the results of Weigel et al. (2003), who demonstrated increased cow survival in herds with fewer cows per employee. In comparing group 1 to group 6 , the results suggest that although larger herds have adopted technology or intensive management practices at a higher frequency, they are not necessarily doing well at achieving improved productivity. In a study of technical efficiency of 273 Wisconsin dairy farms, Cabrera et al. (2010) found that although increased herd size is associated with increased production, it is not a significant determinant of efficiency of dairy farms. Adoption of technology and how efficiently inputs are used are stronger indicators of the productivity of a dairy, not the number of cows that are milked (Cabrera et al., 2010).

\section{Group 2}

Brotzman et al. (2015) discussed the many similarities between group 1 and group 2 herds on DHI variable performance, including a statistically similar mean TCI score $(188 \pm 305 \mathrm{~kg})$ and low LSCS $(2.4 \pm 0.4)$. Although ECM was slightly lower in group 2 (38.7 \pm 4.6) than in group $1(42.3 \pm 3.6)$, the survey of group 2 revealed a different management scheme capable of achieving high levels of overall herd performance with one of the smallest mean herd sizes $(317 \pm 261$ cows $)$. Group 2 herds tended to use intensive management practices and technologies less often than group 1 and group 6 herds, including SYNCH (60.6\%), rbST (33.3\%), and separation of primiparous from multiparous cows (48.5\%; least of all groups). Group 2 was also less reliant on SYNCH compared with previous surveys where such strategies were more widely adopted. For example, Caraviello et al., (2006) found that $86 \%$ of progeny-testing herds in strong dairy states in the United States used synchronization for first breeding, yet mean DIM was lowest for group $2(178 \pm 11 \mathrm{~d})$ in the current study. Use of rbST in group 2 was similar to previous results of a survey of herds of 200 to 499 cows in Wisconsin conducted by the USDA National Agricultural Statistics Service (USDA-NASS, 2010), with $37 \%$ of herds reporting use of rbST and a mean treatment rate of $59 \%$ of cows in the herd. Although separating primiparous cows from older animals has been demonstrated to improve feeding time, intakes, and milk production (Krohn and Konggaard, 1979) as well as lying time (Grant and Albright, 2001), this is often difficult to do in smaller herds, such as those in group 2. However, 2-row pen designs were most common among group 2 herds $(69.7 \%)$ and this pen design serves to provide more feed space per cow, which is an important factor in decreasing agonistic interactions and increasing feeding activity, particularly for lowranking cows ((DeVries et al., 2004; Friend et al., 1977; Huzzey et al., 2006).

Group 2 herds appeared to work toward higher standards of production with fewer inputs, such as milking only twice daily (100\%) in the smallest and undersized parlors (17 \pm 5 units; $7.8 \pm 3.7$ turns required for the largest milking group), with the smallest workforce (5.3 \pm 2.7 FTE) covering one of the largest numbers of cows/ FTE (59 \pm 16 cows/FTE). Increased milk production due to increased milking frequency is well documented both for individual cows (Erdman and Varner, 1995) and herds as surveyed by Smith et al. (2002) using DHI 
BROTZMAN ET AL.

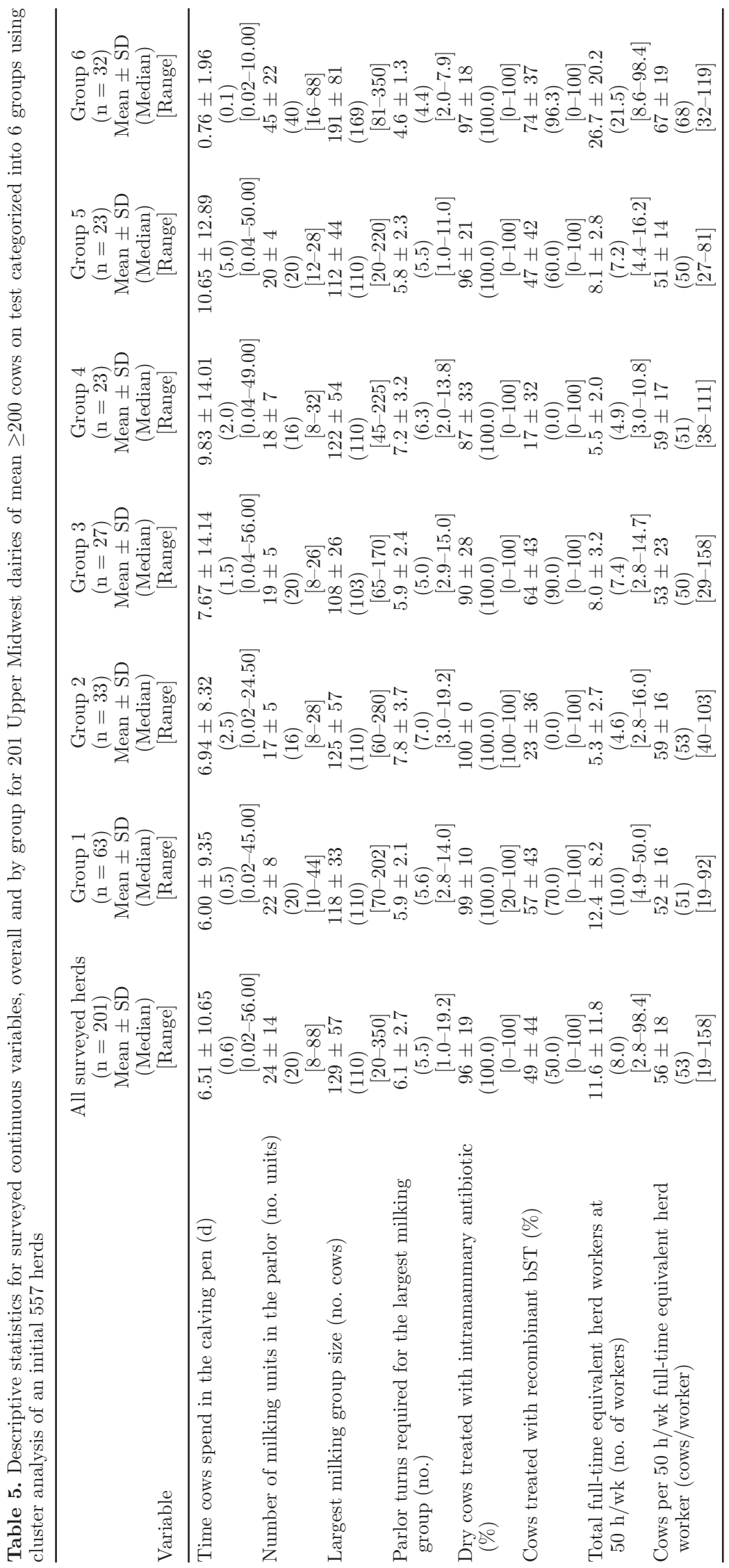




\begin{tabular}{|c|c|c|c|c|c|c|}
\hline \multirow[b]{2}{*}{ Survey Variable } & \multicolumn{6}{|c|}{ Cluster Group Rank } \\
\hline & $\begin{array}{c}\text { Group } \\
1\end{array}$ & $\begin{array}{l}\text { Group } \\
2\end{array}$ & $\begin{array}{c}\text { Group } \\
3\end{array}$ & $\underset{4}{\text { Group }}$ & $\begin{array}{l}\text { Group } \\
5\end{array}$ & $\begin{array}{l}\text { Group } \\
6\end{array}$ \\
\hline $\begin{array}{l}\text { Reproductive synchronization program is routinely used } \\
\text { for the first breeding in adult cows }\end{array}$ & 2 & 4 & 5 & 6 & 3 & 1 \\
\hline Recombinant bovine somatotropin is used on the dairy & 2 & 5 & 3 & 6 & 4 & 1 \\
\hline Custom calf or heifer raiser is used & 2 & 5 & 4 & 6 & 3 & 1 \\
\hline Two dry period ration groups are used & 2 & 4 & 5 & 6 & 3 & 1 \\
\hline Cows receive hoof trimming on a scheduled basis & 2 & 5 & 3 & 4 & 6 & 1 \\
\hline $\begin{array}{l}\text { Two or more scheduled hoof trims per lactation are } \\
\text { performed }\end{array}$ & 1 & 5 & 4 & 6 & 3 & 2 \\
\hline Heifers receive hoof trimming on a scheduled basis & 2 & 5 & 3 & 6 & 4 & 1 \\
\hline $\begin{array}{l}\text { Primiparous cows are housed separately from multiparous } \\
\text { cows }\end{array}$ & 2 & 6 & 3 & 5 & 4 & 1 \\
\hline $\begin{array}{l}\text { Headlocks are used along the feed bunk for the mature, } \\
\text { high producing cows }\end{array}$ & 3 & 5 & 2 & 4 & 6 & 1 \\
\hline $\begin{array}{l}\text { Fresh feed is delivered to the mature, high producing cows } \\
\text { twice or more per day }\end{array}$ & 5 & 2 & 6 & 1 & 3 & 4 \\
\hline $\begin{array}{l}\text { Methods other than automatic alley scraping are used to } \\
\text { clean pen alleys }\end{array}$ & 3 & 5 & 4 & 1 & 1 & 2 \\
\hline $\begin{array}{l}\text { Freestalls for the mature, high producing cows have a deep } \\
\text { bedded surface }\end{array}$ & 2 & 4 & 5 & 3 & 6 & 1 \\
\hline $\begin{array}{l}\text { Two-row stall layout is used for the mature, high } \\
\text { producing cow freestall pen }\end{array}$ & 3 & 1 & 2 & 6 & 4 & 5 \\
\hline $\begin{array}{l}\text { Parlor turns to milk the largest group of cows (lowest }=1 \text {; } \\
\text { highest }=6 \text { ) }\end{array}$ & 3 & 6 & 4 & 5 & 2 & 1 \\
\hline $\begin{array}{l}\text { Cows per } 50-\mathrm{hr} \text { per week full time equivalent worker } \\
\text { (highest cows/FTE }=1 \text {; lowest cows/FTE }=6 \text { ) }\end{array}$ & 5 & 2 & 4 & 3 & 6 & 1 \\
\hline
\end{tabular}

\section{FTE: 50-hr per week full-time equivalent worker}

Figure 1. Relative rank of cluster groups by highest rate of adoption of select survey variables of technology, management, and housing practices demonstrating wide range of variation between groups and that promote improved production, animal well-being, and labor efficiency. Ranking is from 1 to 6 , with 1 and 6 indicating the highest and lowest rates of adoption, respectively. Color variation toward dark gray indicates highest adoption rate among groups, whereas color variation toward white indicates lowest adoption rate among groups. Color version available online.

records for dairies located in the Midwest and eastern portion of the United States. Decreased milking frequency may explain the lower milk production of group 2 versus group 1. A survey of high-producing dairy herds in British Columbia, California, and the northeastern United States found that twice-daily milking was performed by approximately $60 \%$ of herds overall, but the vast majority of herds in the western regions milked 3 times daily ( 79.5 to $85.7 \%$; von Keyserlingk et al., 2012). Wagner et al. (2001) reported that dairy farms using stall barns with a pipeline or flat parlors in an old barn required more turns per hour (6.61 and
6.10 turns/h, respectively) than pit parlors in either old or new buildings (4.57 and 4.32 turns/h, respectively), and group 2 contained the most number of step-up, flat barn, and tiestall or stanchion parlors among all 6 cluster groups. Adding to the workload was an increased tendency toward raising their own calves and heifers (only $24.2 \%$ of group 2 herds utilized CUST) and increased frequency of fresh feed delivery $(48.5 \%)$, although this may help group 2 herds encourage cows to visit the feedbunk more often, potentially increasing feed intake and subsequent milk production than in other groups (DeVries et al., 2003; Mentink and Cook, 
2006). Automatic alley scraping, a labor-saving practice, was more commonly used among group 2 herds (30.3\%). In a previous survey of Wisconsin dairies, automatic alley scrapers were used on only $11 \%$ of farms (Bewley et al., 2001a). Perhaps group 2 herds achieved as well or more than other groups due to a greater level of skill of their managers and laborers and a willingness to use labor over technologies (e.g., achieving success in observing cows for standing heats vs. relying on a reproductive synchronization program). However, this survey was not designed to assess proficiency of the work force or reasons behind managerial choices.

\section{Group 4}

Group 4 herds also tended not to utilize intensive management practices for production as frequently as groups 1 and 6, and employed smaller workforces for similarly small mean herd sizes as group 2 (312 \pm 130 cows), but did not meet the higher standards of production of the latter. Synchronization, rbST, and monensin were least commonly used among group 4 herds $(39.1,26.1$, and $60.9 \%$, respectively), with only a small proportion of each herd being treated with rbST $(17 \pm 32 \%)$. Yet, group 4 had one of the lowest CULL rates among the 6 groups $(32.3 \pm 8.8 \%)$, mean proportion of the herd that died $(4.9 \pm 2.0 \%)$, and the lowest mean proportion of the herd that died by 60 DIM (1.6 $\pm 0.8 \%)$.

Numerically, group 4 herds on average treated a smaller proportion of their cows with an intramammary antibiotic at dry off $(87 \pm 33 \%)$, reflected in the lowest $\mathrm{DC}$ risk of all 6 groups $(57.7 \pm 15.6 \%)$. Indeed, the poorest mean group performances in the measured DHI milk quality variables were found in group 4 (LSCS 3.0 \pm 0.3 ; NINF $14.9 \pm 3.4 \%$; INF1 $20.2 \pm 5.5 \%$ ), and onfarm testing of treated cows before adding their milk to the saleable tank was least common among this group $(34.8 \%)$.

The size and scale of available labor on group 4 farms was very similar to that of group 2 , with $5.5 \pm 2.0 \mathrm{FTE}$ and $59 \pm 17$ cows/FTE - the smallest mean workforce sizes among the 6 groups. Most herds milked twice daily $(73.9 \%)$ in smaller, undersized parlors $(18 \pm 7$ units; $7.2 \pm 3.2$ turns required for the largest milking group), with more than one-third using swing parlors (39.1\%). Much more labor was spent on calf and heifer raising on group 4 farms; $87 \%$ of group 4 herds raised their own young stock, compared with the overall rate of $59.2 \%$ of all surveyed herds. In comparison, $72 \%$ of large, progeny-testing dairies in a US survey reported raising their own heifer calves versus sending them offfarm to a heifer raiser or selling them (Caraviello et al., 2006). Scheduled hoof trimming of heifers before calving was least commonly performed among group 4 herds $(17.4 \%)$. These herds' homegrown heifers tended to have a delayed entrance into the milking herd, as group 4's mean AGE1 was one of the highest (25.0 \pm $1.4 \mathrm{mo}$ ). The lack of preventative hoof care and late AGE1 may point to either an inadequately sized labor force on group 4 dairies, an unwillingness to implement management strategies to improve well-being and performance, or perhaps a combination of both.

The majority of herds utilizing pasture access for mature, high-producing cows were found in group 4 (30.4\% of group 4 herds). For comparison, a relatively recent survey of Wisconsin dairy herds of 200 to 499 cows in size found that only $9 \%$ of herds allowed their cows to graze and none of the surveyed dairies with $\geq 500$ cows allowed lactating herds access to pasture (USDANASS, 2010). Dairy farms that use pasture have previously been shown to have lower milk production (Bargo et al., 2002) and tend toward lower technical efficiency (Cabrera et al., 2010). However, allowing lactating cows access to pasture can improve locomotion scores (Haskell et al., 2006; Hernandez-Mendo et al., 2007). The largest proportion of 3-row pens for multiparous, high producing cows was also found in group $4(65.2 \%)$, which may also have affected performance. Overall, this survey found similar proportions of herds using 2- or 3 -row freestall pens to a previous survey (46 and 48\%, respectively; Bewley et al., 2001a), but group 4 herds tended to use this design. Cow behavior is negatively affected when space per cow is limited at the feed bunk (DeVries et al., 2004; Friend et al., 1977) and this is particularly true for low-ranking cows within an overstocked group relative to feed-bunk space (Huzzey et al., 2006).

Individual pens for calving cows were not common among all herds in this survey $(37.8 \%)$, and were least commonly adopted among group 4 herds $(21.7 \%)$. The Dairy 2007 USDA survey found that individual calving pens were used on $42.0 \%$ of medium (100 to 499 cows) and $43.8 \%$ of large $(\geq 500$ cows $)$ dairy farms throughout the United States (USDA-APHIS VS, 2010). Hoe and Ruegg (2006) reported $47.8 \%$ of large (>200 cows) Wisconsin dairy farms used individual calving pens, and a 1999 survey found that $43 \%$ of expanding Wisconsin dairies used individual calving pens (Bewley et al., 2001a). Average duration of stay in the calving pen was longer than previously described for all herds surveyed $(6.51 \pm 10.65 \mathrm{~d})$ and for group 4 in particular $(10.65 \pm 12.89 \mathrm{~d})$, compared with the mean duration of stay in the calving pen of $2.4 \pm 1.1 \mathrm{~d}$ in a survey of 103 large, progeny-testing herds throughout the United States (Caraviello et al., 2006). More research is needed to better describe current prefresh pen and calving pen management and its effect on newborn and transition 
cow health and performance to help explain this apparent trend toward longer stays in group calving pens.

\section{Group 5}

Group 5 herds used production-enhancing technologies at a high rate; for example, rbST and monensin were more commonly used among group 5 herds (60.9 and $91.3 \%$, respectively) than in other groups. However, ECM was one of the lowest and DIED $(12.5 \pm 2.9 \%)$ and DIED60 $(5.8 \pm 1.5 \%)$ were the highest among the 6 groups. This performance, combined with the lowest mean TCI $(-266 \pm 255 \mathrm{~kg})$, suggests that group 5 herds may have some housing and management factors impeding their performance potential, and their survey responses provide some clues.

Group 5 herds used sand bedding least often (52.2\%) and used a rubber mat or mattress stall surface most often (39.1\%). Rates of sand bedding use vary by region and tend to be higher in Wisconsin than in the nation as a whole. Sand bedding was used on $52 \%$ of dairy farms in a 2008 survey of expanding Wisconsin dairies by Mayer and Kammel (2008), with mattresses used by $27 \%$ of farms, whereas nationally across all herd sizes, the USDA found that only $45.0 \%$ of freestall operations used sand bedding in 2007 (USDA-APHIS VS, 2010). In some regions, sand use is even lower, being found in only $17.4 \%$ of herds in a recent survey of highproduction herds in British Columbia, California, and the northeastern United States (von Keyserlingk et al., 2012). Stall surface and bedding type has production and animal welfare implications that may contribute to the poor performance of group 5. Bewley et al. (2001a) found that among expanding Wisconsin dairies, herds that used sand bedding had lower culling rates than herds with mattresses (29 vs. 34\%, respectively). Sand bedding has been associated with lower rates of lameness in Midwestern regions (Cook et al., 2004; Espejo et al., 2006) and in a survey of dairies located in the northeastern United States and California (Chapinal et al., 2013). Further implicating lameness as a potential cause of overall poorer DHI performance in group 5 is the lack of scheduled hoof trimming, with $34.8 \%$ of herds failing to perform regular maintenance trimming on cows. Although this rate is not far from that in a previous survey of large, progeny-test herds throughout the United States, with $69 \%$ conducting maintenance trimming twice or more per year (Caraviello et al., 2006), $83.1 \%$ of all herds in the current survey performed one or more scheduled maintenance trims on cows each lactation, making group 5 exceptional. Headlocks were least commonly used among group 5 herds $(56.5 \%)$. Headlocks assist workers in the examination and identification of sick cows in freestall pens and have been shown to decrease aggressive displacements of cows from feeding compared with a post-and-rail feed barrier (Endres et al., 2005; Huzzey et al., 2006). Nationally, the USDA found $22.2 \%$ of medium (100 to 499 cows) and $79.6 \%$ of large ( $\geq 500$ cows) dairies used headlocks at the feed bunk in 2010. A post-and-rail barrier was used by 37.1 and $15.7 \%$ of medium and large herds, respectively (USDA-APHIS VS, 2010).

\section{Group 3}

Similar to the unclear pattern of results from the CA (Brotzman et al., 2015), the survey results of group 3 herds did not show clear trends in management, housing, or technology adoption. Pharmacological technology use was often moderate but not overwhelming among group 3 herds, including use of $\mathrm{SYNCH}$ $(59.3 \%)$, internal teat sealant at dry off $(77.8 \%)$, rbST (70.4\%), and monensin $(77.8 \%)$. This pattern continued for management and housing practices such as use of scheduled hoof trimming of the adult herd (77.8\%), separate groups for primiparous and multiparous lactating cows $(74.1 \%)$, and use of sand bedding for the mature, high-producing cow pen (63\%). Still, all of group 3 herds utilized 3 -times-daily milking routines and had the highest rate of once-daily feed delivery $(63 \%)$, suggesting efficient use of labor resources.

The lack of consistency in answers among group 3 herds may point toward this cluster group as a "catchall" for dairies that simply do not fit well with any of the other 5 cluster groups, may represent an "average" performing and managed dairy in the Upper Midwest, or may indicate a failure of this survey instrument in its ability to define the stereotypical herd that belongs to group 3.

\section{Implications of Survey Results}

Multivariable dairy herd performance as categorized by $\mathrm{CA}$ was associated with patterns of management revealed in the survey, despite likely underlying similarities in general management practices due to the size of the herds studied. Although herds of 200 or more cows are most likely to be managed similarly - being housed in freestall barns and milked in a parlor (USDA-NASS, 2010) - dairies of this size that are often categorically described as "large" or "intensified" in their management practices can be classified into different levels of performance (Brotzman et al., 2015). This survey demonstrated that these categories of performance are associated with the presence or absence of management factors, providing opportunity for consultants and outreach educators to better tailor efforts toward a certain type of dairy rather than taking a blanket approach to 
applying recommendations to farms simply because of their larger herd size.

\section{CONCLUSIONS}

A survey of management practices of dairy herds clustered by PCA-selected DHI variables was useful for understanding the group outcomes of CA. Hypotheses generated by the resulting categorization of herds appear to be supported by patterns of management associated with improved herd performance as revealed by the survey. Because dairy farm operators manage their herds with different levels of skill and available resources, it can be expected that technologies and practices will be implemented to variable degrees or competencies on each farm, resulting in variable effects on production and potentially few variables that could explain the overall performance of a dairy. Although determining which management factors best predict measures of production is obviously important, additional work is still needed to study the potential use of DHI information and surveyed management practices to predict animal health and welfare indicators that also affect the overall performance of a dairy herd. Investigation into specific management and housing factors that contribute to DHI-measured variables of animal well-being such as culling, death, and disease rates is a clear objective. Additionally, work is needed to examine the effectiveness of improved housing and management for prevention of issues of animal well-being, such as lameness and other musculoskeletal injuries, while accounting for production gains or losses. Future investigation should focus on how to assist producers in lesser-performing groups to either better utilize or successfully adopt management best practices, facility design, and technologies for improved overall production performance. More work should also be done to describe how labor is best utilized on dairy farms for promoting improved overall performance.

\section{ACKNOWLEDGMENTS}

The authors express appreciation to each dairy producer who devoted time to answering these survey questions. We are grateful for the assistance of personnel and access to dairy herd data at AgSource Cooperative Services (Verona, WI) and for statistical support provided by Cecile Ane and Nicholas Keuler (Department of Statistics, University of Wisconsin-Madison). The study was supported by the Summer Scholars program at UW-Madison School of Veterinary Medicine and by the supporters of the Dairyland Initiative (http://thedairylandinitiative.vetmed.wisc.edu/prv_supporters. htm).

\section{REFERENCES}

Bargo, F., L. D. Muller, J. E. Delahoy, and T. W. Cassidy. 2002. Performance of high producing dairy cows with three different feeding systems combining pasture and total mixed rations. J. Dairy Sci. 85:2948-2963.

Bewley, J., R. W. Palmer, and D. B. Jackson-Smith. 2001a. A comparison of free-stall barns used by modernized Wisconsin dairies. J. Dairy Sci. 84:528-541.

Bewley, J., R. W. Palmer, and D. B. Jackson-Smith. 2001b. An overview of experiences of Wisconsin dairy farmers who modernized their operations. J. Dairy Sci. 84:717-729.

Borcard, D. 2011. Numerical Ecology with R. Springer, New York, NY.

Brotzman, R.L., N. B. Cook, K. Nordlund, T. B. Bennett, A. Gomez Rivas, and D. Döpfer. 2015. Cluster analysis of Dairy Herd Improvement data to discover trends in performance characteristics in large Upper Midwest dairy herds. J. Dairy Sci. 98:3059-3070. http://dx.doi.org/10.3168/jds.2014-8369.

Cabrera, V. E., D. Solís, and J. del Corral. 2010. Determinants of technical efficiency among dairy farms in Wisconsin. J. Dairy Sci. 93:387-393.

Caraviello, D. Z., K. A. Weigel, P. M. Fricke, M. C. Wiltbank, M. J. Florent, N. B. Cook, K. V. Nordlund, N. R. Zwald, and C. L. Rawson. 2006. Survey of management practices on reproductive performance of dairy cattle on large U.S. commercial farms. J. Dairy Sci. 89:4723-4735.

Chapinal, N., A. K. Barrientos, M. A. G. von Keyserlingk, E. Galo, and D. M. Weary. 2013. Herd-level risk factors for lameness in freestall farms in the northeastern United States and California. J. Dairy Sci. 96:318-328.

Cook, N. B., T. B. Bennett, and K. V. Nordlund. 2004. Effect of free stall surface on daily activity patterns in dairy cows with relevance to lameness prevalence. J. Dairy Sci. 87:2912-2922.

Cook, N. B., and K. V. Nordlund. 2004. Behavioral needs of the transition cow and considerations for special needs facility design. Vet. Clin. North Am. Food Anim. Pract. 20:495-520.

deVries, M., E. A. M. Bokkers, T. Dijkstra, G. van Schaik, and I. J. M. de Boer. 2011. Invited review: Associations between variables of routine herd data and dairy cattle welfare indicators. J. Dairy Sci. 94:3213-3228.

DeVries, T. J., M. A. G. von Keyserlingk, and K. A. Beauchemin. 2003. Short communication: Diurnal feeding pattern of lactating dairy cows. J. Dairy Sci. 86:4079-4082.

DeVries, T. J., M. A. G. von Keyserlingk, and D. M. Weary. 2004. Effect of feeding space on the inter-cow distance, aggression, and feeding behavior of free-stall housed lactating dairy cows. J. Dairy Sci. 87:1432-1438.

Endres, M. I., T. J. DeVries, M. A. G. von Keyserlingk, and D. M. Weary. 2005. Short Communication: Effect of feed barrier design on the behavior of loose-housed lactating dairy cows. J. Dairy Sci. 88:2377-2380.

Enevoldsen, C., J. T. Sørensen, I. Thysen, C. Guard, and Y. T. Gröhn. 1995. A diagnostic and prognostic tool for epidemiologic and economic analyses of dairy herd health management. J. Dairy Sci. 78:947-961.

Erdman, R. A., and M. Varner. 1995. Fixed yield responses to increased milking frequency. J. Dairy Sci. 78:1199-1203.

Espejo, L. A., M. I. Endres, and J. A. Salfer. 2006. Prevalence of lameness in high-producing Holstein cows housed in freestall barns in Minnesota. J. Dairy Sci. 89:3052-3058.

Friend, T. H., C. E. Polan, and M. L. McGilliard. 1977. Free stall and feed bunk requirements relative to behavior, production and individual feed intake in dairy cows. J. Dairy Sci. 60:108-116.

Galligan, D. 2006. Economic assessment of animal health performance. Vet. Clin. North Am. Food Anim. Pract. 22:207-227.

Galligan, D. T. 1999. The economics of optimal health and productivity in the commercial dairy. Rev. Sci. Tech. 18:512-519.

Grant, R. J., and J. L. Albright. 2001. Effect of animal grouping on feeding behavior and intake of dairy cattle. J. Dairy Sci. 84(E. Suppl.):E156-E163. 
Haskell, M. J., L. J. Rennie, V. A. Bowell, M. J. Bell, and A. B. Lawrence. 2006. Housing system, milk production, and zero-grazing effects on lameness and leg injury in dairy cows. J. Dairy Sci. 89:4259-4266.

Hernandez-Mendo, O., M. A. G. von Keyserlingk, D. M. Veira, and D. M. Weary. 2007. Effects of pasture on lameness in dairy cows. J. Dairy Sci. 90:1209-1214.

Hoe, F. G. H., and P. L. Ruegg. 2006. Opinions and practices of Wisconsin dairy producers about biosecurity and animal well-being. J. Dairy Sci. 89:2297-2308.

Huzzey, J. M., T. J. DeVries, P. Valois, and M. A. G. von Keyserlingk. 2006. Stocking density and feed barrier design affect the feeding and social behavior of dairy cattle. J. Dairy Sci. 89:126-133.

Khanal, A. R., J. Gillespie, and J. MacDonald. 2010. Adoption of technology, management practices, and production systems in US milk production. J. Dairy Sci. 93:6012-6022.

Krohn, C. C., and S. P. Konggaard. 1979. Effects of isolating firstlactation cows from older cows. Livest. Prod. Sci. 6:137-146.

Mayer, M. W., and D. W. Kammel. 2008. 2008 Dairy Modernization Survey. Accessed Jun. 28, 2013. https://www.extension.org/ pages /64455/2008-wisconsin-dairy-modernization-survey\#.U_ NsUmNhvYQ

Mentink, R. L., and N. B. Cook. 2006. Short communication: Feed bunk utilization in dairy cows housed in pens with either two or three rows of free stalls. J. Dairy Sci. 89:134-138.

Nordlund, K. V. 2011. Cow comfort drives transition cow success. Pages 97-101 in Proc. Four-State Dairy Nutr. Manag. Conf. Dubuque, IA. MidWest Plan Service, Ames, IA.

Oleggini, G. H., L. O. Ely, and J. W. Smith. 2001. Effect of region and herd size on dairy herd performance parameters. J. Dairy Sci. 84:1044-1050.

SAS Institute. 2008. SAS User Guide. Version 9.2. SAS Institute Inc., Cary, NC.

Schefers, J. M., K. A. Weigel, C. L. Rawson, N. R. Zwald, and N. B. Cook. 2010. Management practices associated with conception rate and service rate of lactating Holstein cows in large, commercial dairy herds. J. Dairy Sci. 93:1459-1467.
Smith, J. W., L. O. Ely, and A. M. Chapa. 2000. Effect of region, herd size, and milk production on reasons cows leave the herd. J. Dairy Sci. 83:2980-2987.

Smith, J. W., L. O. Ely, W. M. Graves, and W. D. Gilson. 2002. Effect of milking frequency on DHI performance measures. J. Dairy Sci. 85:3526-3533.

USDA-APHIS VS (Animal and Plant Health Inspection Service, Veterinary Services). 2010. Dairy 2007: Facility characteristics and cow comfort on U.S. dairy operations, 2007. Accessed August 4 2014. http://nvap.aphis.usda.gov/animal_health/nahms/dairy/ downloads/dairy07/Dairy07_ir_Facilities.pdf.

USDA-NASS (National Agricultural Statistics Service). 2010. Wisconsin Dairy Producer Survey 2010. Accessed May 7, 2013. http:// www.nass.usda.gov/Statistics_by_State/Wisconsin/Publications/ Dairy/Dairy_OP_Release_10.pdf.

USDA-NASS (National Agricultural Statistics Service). 2012. Milk production, measured in percent by size group. Accessed October 3, 2014. http://quickstats.nass.usda.gov/results/6D9F2D7AD25A-3AC5-866B-EF3F5C1B57EE?pivot=short_desc.

von Keyserlingk, M. A. G., A. Barrientos, K. Ito, E. Galo, and D. M. Weary. 2012. Benchmarking cow comfort on North American freestall dairies: Lameness, leg injuries, lying time, facility design, and management for high-producing Holstein dairy cows. J. Dairy Sci. 95:7399-7408.

von Keyserlingk, M. A. G., N. P. Martin, E. Kebreab, K. F. Knowlton, R. J. Grant, M. Stephenson, C. J. Sniffen, J. P. Harner III, A. D. Wright, and S. I. Smith. 2013. Invited review: Sustainability of the US dairy industry. J. Dairy Sci. 96:5405-5425.

Wagner, A., R. W. Palmer, J. Bewley, and D. B. Jackson-Smith. 2001. Producer satisfaction, efficiency, and investment cost factors of different milking systems. J. Dairy Sci. 84:1890-1898.

Weigel, K. A., R. W. Palmer, and D. Z. Caraviello. 2003. Investigation of factors affecting voluntary and involuntary culling in expanding dairy herds in Wisconsin using survival analysis. J. Dairy Sci. 86:1482-1486. 